\title{
Stocking Rate and Energy Supplementation Effects on Replacement Beef Heifers Grazing Annual Ryegrass
}

\author{
Guillermo Scaglia ${ }^{1}$ \\ ${ }^{1}$ Louisiana State University Agricultural Center Iberia Research Station, Jeanerette, Louisiana, USA \\ Correspondence: Guillermo Scaglia, Louisiana State University Agricultural Center Iberia Research Station, \\ Jeanerette, Louisiana, 70544, USA. Tel: 337-276-5527. E-mail: gscaglia@agcenter.lsu.edu
}

Received: November 4, 2018

Accepted: December 10, 2018

Online Published: February 15, 2019

doi:10.5539/jas.v11n3p1

URL: https://doi.org/10.5539/jas.v11n3p1

This work was supported by the USDA National Institute of Food and Agriculture, Hatch project 1004419.

\begin{abstract}
The development of breeding heifers is a critical point in the beef cattle enterprise. The effect of stocking rate and supplementation strategy at high stocking rate were evaluated on Brahman influenced heifers (BW = $250 \pm 3.6 \mathrm{~kg}$ ) continuously stocked on annual ryegrass (Lolium multiflorum Lam. cv. 'Nelson') with the following treatments in a completely randomized design with 3 replicates: 1) LOW stocking rate (2.5 heifers/ha); 2) MED stocking rate (5.0 heifers/ha); 3) HIGH stocking rate (7.5 heifers/ha); 4) High stocking rate $+1 \%$ BW of ground corn $(\mathrm{HIGH}+\mathrm{C})$; and 5$)$ High stocking rate $+1 \% \mathrm{BW}$ of soybean hulls $(\mathrm{HIGH}+\mathrm{SBH})$. Dry matter intake was greater $(P=0.03)$ for heifers in LOW and MED, while those in HIGH, regardless receiving supplement or not, were the lowest. Heifers grazing LOW and MED did not differ $(P=0.06)$ in ADG. Supplemented heifers and those in MED produced the most beef per unit of land; however MED and HIGH were not significantly different. Grazing days was greater for LOW and supplemented heifers. There was a year effect for ADG, beef production, and grazing days which were smaller in year 1 ; however years 2 and 3 were not different $(P>0.05)$ between them except in production per hectare. Lower stocking rates allowed for appropriate BW gains. Level of supplementation affected DMI from ryegrass, replacing it and affecting animal performance. Weather conditions had an impact on forage production, hence affecting animal performance. Supplementation programs must consider level and type of energy supplement used.
\end{abstract}

Keywords: annual ryegrass, beef heifers, ground corn, soybean hulls, stocking rate, supplementation

\section{Introduction}

In today's economic environment reducing costs in beef cattle enterprises is the goal for many producers. Heifer development is a crucial step to maintain an efficient and profitable herd. Normally, heifers are bred with 14-15 months of age, two to three weeks before the rest of the herd. This difference will provide them with more time to recover after calving, hence starting their second breeding season in better condition (Funston \& Deutscher, 2004). However, this program requires heifers to have a greater rate of gain to reach the appropriate BW. Stocking rate, defined as the relationship between the number of animals and the grazing management unit utilized over a specified time period (Forage and Grazing Terminology Committee, 1991), is the most important management variable affecting the grazing enterprise. Determining stocking rates requires knowledge of forage production and grazing pressure. Many factors can affect forage availability including weather but it also varies from pasture to pasture and locations within a pasture (Ohlenbusch \& Watson, 1994). Stocking rate determines animal performance, financial return and the long-term condition of the pastures. Proper stocking rates will: 1) produce optimum animal performance; 2) make the farm/ranch profitable; and 3) sustain or improve the forage resource (White \& McGinty, 1999). Maximum individual animal performance occurs at light stocking rates because there is little competition for the best forage plants in the pasture. As stocking rate is increased, the level of individual animal performance is reduced due to increased competition but the production per unit of land is increased up to a threshold and then declines (Mott, 1960). Energy intake is the primary nutritional consideration for reproductive development of beef heifers (Maas, 1987). Hence, energy supplementation is often required in cow-calf production systems, particularly those based on low-quality forages (Schillo, Hall, \& Hileman, 1992; Roberts, Nugent III, Klindt, \& Jenkins, 1997). However, the expenses associated with energy supplementation 
can significantly increase production costs and become unattractive to cow-calf producers. Supplementation (adding one or more nutrients that is/are deficient in a basal diet) can help cattle perform at their best, aim at extending the grazing season (because less forage is consumed), and/or sustain greater number of animals per unit of land than if not supplemented. Animal response to energy supplementation on grazing systems will depend on availability and nutritive value of pasture, and on level, palatability, and nutritional composition of supplemented concentrate (Horn \& McCollum, 1987). Rearte and Pieroni (2001) concluded that when grazing cattle are supplemented with energy supplements there are two important factors affecting intake: 1) how much the dry matter intake from pasture is decreased due to the supplementation with the concentrate, and 2) an energy supplement (grains for example) depressed fiber digestion and its extent depends on the amount supplemented. Soybean hulls (SBH), a by-product of soybean processing, are nearly balanced in protein (12 to $14 \%$ ), calcium $(0.63 \%)$, and phosphorus $(0.23 \%)$ for supplementing beef cattle (National Academies of Sciences, Engineering, and Medicine. 2016). They are palatable and the risk of acidosis is low; consequently, this commodity feed is often fed without blending with other ingredients. Grains are usually more digestible than forages; however, digestibility in the entire gastrointestinal tract of mixed grain-forage diets is affected due to the reduced digestion of the fibrous components of the forage (Van der Linden, Van Gylswyk, \& Schwartz, 1984; Kennedy \& Bunting, 1992; Grigsby, Kerley, Paterson, \& Weigel, 1993). Ruminants can partially compensate for a reduced rate of fiber digestion in the rumen by increasing retention time of fibrous residues in this compartment, but when this occurs forage intake usually decreases (Dixon \& Stockdale, 1999). The objective was to compare the development of beef heifers grazing annual ryegrass at different stocking rates and energy supplemented at the greatest of these stocking rates.

\section{Materials and Methods}

The present study was conducted at the Louisiana State University Agricultural Center Iberia Research Station (IRS) located in Jeanerette, LA ( $29^{\circ} 57^{\prime} 54^{\prime \prime}$ W latitude; $91^{\circ} 42^{\prime} 54^{\prime \prime} \mathrm{N}$ longitude; altitude $\left.5.5 \mathrm{~m}\right)$. The soil type is classified as Iberia silty clay loam poorly drained with risk of flooding; however, the area was shaped ('turtle-back') to improve drainage.

\subsection{Weather Data}

Monthly information on average temperatures $\left({ }^{\circ} \mathrm{C}\right)$ and rainfall $(\mathrm{mm})$ was obtained from a weather station located at the IRS approximately $230 \mathrm{~m}$ from the center of the experimental site. Historic monthly average weather data for the period 1970 to 2018 were obtained from http://www.nws.noaa.gov/climate/xmacis.php? wfo $=$ lch (select Jeanerette, LA).

\subsection{Cattle Management and Treatments}

Ninety crossbred (Bos taurus $\times$ B. indicus; up to $1 / 3$ Brahman influence) heifers (BW $=250 \pm 3.6 \mathrm{~kg} ; 11 \pm 0.2 \mathrm{mo}$ of age) were used in 3 consecutive yr (2011-2012, 2012-2013, and 2013-2014). Two weeks before the experiment began heifers were weighed in 2 consecutive days, their BW averaged and were randomly allotted to five treatments (3 replicates per treatment; 6 heifers per treatment/replicate): 1) LOW stocking rate heifers were continuously stocked on annual ryegrass (Lolium multiflorum Lam. cv. 'Nelson') pastures ( 2.5 heifers/ha; 2.4 ha per replicate); 2) MED stocking rate heifers (5.0 heifers/ha; 1.2 ha per replicate); 3) HIGH stocking rate heifers (7.5 heifers/ha; 0.8 ha per replicate); 4) High stocking rate heifers $+1 \% \mathrm{BW}$ of ground corn $(\mathrm{HIGH}+\mathrm{C})$; and 5) High stocking rate heifers $+1 \%$ BW of soybean hulls $(\mathrm{HIGH}+\mathrm{SBH})$. During these 2 weeks, heifers in supplemented treatments were accustomed to their respective type and amount of supplement. On d 0 , heifers were placed in their respective pasture. The area of them was adjusted for the stocking rates since all groups had 6 heifers. Divisions were created using 2 lines of polytape and plastic posts. At the start of the experiment (d 0), heifers were weighed again on 2 consecutive days ( $\mathrm{d}-1$ and $\mathrm{d} 0)$ with no restriction of grazing or water, weights averaged (BW for $\mathrm{d} 0$ ) and every $15 \mathrm{~d}$ thereafter to determine ADG per 15-d period and total ADG for the grazing period (at the end of the experiment heifers were also weighed in 2 consecutive days). Beef produced per unit of land was estimated by the difference between final and starting BW divided by the area of each paddock. On d 0 and 45 of the experimental period heifers were dewormed with Ivomec Plus Injectable (Merial; Duluth, GA). A commercial mineral mix that guaranteed $12 \% \mathrm{Ca}, 6 \% \mathrm{P}, 10 \% \mathrm{NaCl}, 2.50 \% \mathrm{Mg}, 0.75 \% \mathrm{~K}, 0.0043 \% \mathrm{Cu}$, $0.00012 \% \mathrm{Se}, 0.0067 \% \mathrm{Zn}, 200,000 \mathrm{IU}$ of Vitamin A was offered ad libitum and fresh water throughout the experimental period. Thirty day before weaning, heifers were vaccinated with Bovishield Gold FP VL5 (Pfizer Animal Health, New York, NY), Clostridium 8-way w/Somnus (Bayer Vision; Intervet, Boxmeer, The Netherlands), Pulmo Guard PHM-1 (Boehringer Ingelheim; Ridgefield, CT) and were dewormed with Valbazen (Albendazole, Pfizer Animal Health). At weaning, they received the booster vaccines and were vaccinated against brucellosis. From weaning to two weeks before the start of the experiment, heifers were fed 
bermudagrass (Cynodon dactylon) hay ad libitum and were fed soybean hulls at $0.5 \%$ of their BW. All procedures involving animals were approved by the LSU AgCenter Institutional Animal Care and Use Committee.

\subsection{Supplement, Pasture Management, Sampling, and Analyses}

Ground corn and soybean hulls were fed daily at approximately 0800 . The amounts fed ( $1 \%$ of BW) were adjusted every $15 \mathrm{~d}$ and average consumption (for each replicate) by period and for the entire experimental period were calculated. Supplements were weighed in polypropylene woven bags using an electronic scale $(454 \pm 0.1 \mathrm{~kg})$ and fed on a 3-m long $\times 70 \mathrm{~cm}$ wide galvanized feed bunk located in each paddock. No orts were registered throughout the experimental period.

Approximately 2 to 3 weeks before planting $2 \mathrm{~L} / \mathrm{ha}$ of carboxylatomethylaminomethyl(oxylato)phosphinic acid were applied to eliminate existing unwanted plant species. An application of $1.5 \mathrm{~L} / \mathrm{ha}$ of 2,4-D was done every year in January for buttercup (Ranunculus spp.) control. Pastures were planted with annual ryegrass (Lolium multiflorum Lam. cv. 'Nelson'). Seeding rate was $45 \mathrm{~kg} / \mathrm{ha}$, and was planted in late September-early October of every year using a 4.5 -m-wide John Deere no-till planter (Model 1590; Moline IL). The planting depth was set at $1.3 \mathrm{~cm}$. All pastures were fertilized with urea (46-0-0) twice per grazing season (40 to $49 \mathrm{~d}$ after planting and again 30 to $35 \mathrm{~d}$ after the grazing season started). Nitrogen rates were 40 and 55 units of $\mathrm{N}$ per hectare, respectively.

Sampling procedures for forage mass, height, and estimated DMI followed Scaglia, Gillespie, Boland, and Wyatt (2009a); Scaglia, Boland, and Wyatt (2009b). Forage mass was determined at the beginning of the trial (d 0) and every $15 \mathrm{~d}$ thereafter using the double sampling technique as described by Sanderson, Rotz, Fultz, and Rayburn (2001), and Vendramini et al. (2006). Forage mass was then used to determine DMI per paddock and used as Yield $_{\text {Grazed }}$ on each sampling day. Briefly, all paddocks were walked in a zig-zag pattern by an observer (the same person every time) who visually identified 10 sections per hectare $(24,12$, and 8 sections for LOW, MED, and HIGH, respectively) that represented the variability observed across the paddocks. In these 10 sections, the area under the plate meter $\left(0.10 \mathrm{~m}^{2}\right)$ was sampled for height and mass. Ten measurements of height $(\mathrm{cm})$ were determined within the area under the plate. The plate meter was then allowed to fall and a plate meter reading $(\mathrm{cm})$ was recorded. Afterwards, the area under the plate was clipped to $2.54 \mathrm{~cm}$ using hand-clippers, avoiding soil contamination. Forage was placed in a paper bag, weighed, and placed in a forced-air oven at $55^{\circ} \mathrm{C}$ for $48 \mathrm{~h}$. After drying, the bag was weighed again for DM determination. Data points generated in each of the paddocks were used to obtain the regression equation (between forage mass and forage height) that allowed the estimation of forage mass for each paddock. In order to have a representative sample of the entire paddock, 30 readings per hectare were obtained from each paddock using the plate meter and values were recorded. These values were then used as the input for the regression equation generated with the data collected, as indicated before. Forage height was estimated using a quadrat $\left(0.25 \mathrm{~m}^{2}\right)$ that was randomly placed 10 times per hectare in each paddock, within which 10 measurements of forage height $(\mathrm{cm})$ were recorded using a ruler. The average of these measurements represented the pasture height for the paddock at the time of sampling. Samples of forage for nutritive value analyses were hand-plucked from every paddock every $14 \mathrm{~d}$, with the pasture walked in a zig-zag pattern and a sample taken every 10 steps. Samples for nutritive value analyses were dried for DM determination in a forced-air oven at $55{ }^{\circ} \mathrm{C}$ for $48 \mathrm{~h}$ (Association of Official Analytical Chemists, 2000). Forage samples were ground to pass a 1-mm screen using a Wiley mill (laboratory mill model 4; Arthur H. Thomas Co., Philadelphia, PA). Forage and supplement samples were sent for analysis to a commercial laboratory (Dairy One Forage Laboratory, Ithaca, NY) and analyzed by wet chemistry. Crude protein was determined by analyzing N content of the samples according to the AOAC (2000) procedure. Determinations of NDF (with amylase and sodium sulfite added to the NDF solution) and ADF (Van Soest, Robertson, \& Lewis, 1991) were made according to the AOAC (2000) procedure with an Ankom 200/220 Fiber Analyzer (Ankom Technology, Macedon, NY), following the procedure of the manufacturer recommended in the operator manual (Ankom Technology, 1997b). The 48-h IVDMD was determined using a Daisy II200/220 Rumen Incubator (Ankom Technology, 1997a), using F57 filter bags that were pre-rinsed in acetone and dried before filling with sample. The incubation period was for $48 \mathrm{~h}$ (Dairy One Forage Laboratory).

Measurements of annual ryegrass growth rate $\left(\mathrm{kg} D \mathrm{DM}\right.$ per day) were conducted. Three $1-\mathrm{m}^{2}$ exclusion cages constructed using cattle panels (squares of $10 \times 10 \mathrm{~cm}$ ) were used in each of the experimental paddocks to block the heifers from grazing the area within it. Once the cages were placed in the paddock they were secured with 2 galvanized T-posts and tied with wire. The cages were placed in the paddock on $\mathrm{d} 0$ and moved to representative areas every $14 \mathrm{~d}$ during the experimental period. An experienced observer walked each of the paddocks at the time of sampling, and based on visual observation of forage mass available and height across the paddocks, 
representative areas of the whole paddock were selected and cages placed. On $\mathrm{d} 0$, a $0.25-\mathrm{m}^{2}$ quadrat was placed on the ground (where the cage was going to be placed) in each of the lower right quadrant of the cages. Forage height was measured 10 times using a ruler, and then the forage within it was clipped at $2.54 \mathrm{~cm}$ above the ground by using hand-clippers. Forage was placed in a paper bag, weighed, and placed in a $55{ }^{\circ} \mathrm{C}$ forced-air oven for $48 \mathrm{~h}$ (AOAC, 2000). Afterward, the bag with the sample was weighed again for DM determination. The average forage mass for the three samples per paddock was used to determine DMI in each paddock as Yield $_{\text {Exclosure }}$ on each sampling date. On $\mathrm{d} 14$, cages were removed and the $0.25 \mathrm{~m}^{2}$ quadrat was placed on the upper left quadrant under the cages (diagonal to the previous cut). Forage height determination and clipping were conducted using the same method as on $\mathrm{d} 0$. Subsequently, cages were moved to another representative area of the paddock, and the process was repeated every $14 \mathrm{~d}$ throughout the experimental period.

Dry matter intake per paddock was estimated following the method of Meyer et al. (2008):

$$
D M I_{\text {paddock }}=\left(\text { Yield }_{\text {Exclosure } t 1}-\text { Yield }_{\text {Grazed to }}\right)-\left(\text { Yield }_{\text {Grazed } t 1}-\text { Yield }_{\text {Grazed to }}\right)
$$

where, t0 is the previous sampling $(\mathrm{d} 0,15,30,45,60,75,90,105)$ and $\mathrm{t} 1$ is the current sampling $(\mathrm{d} 15,30,45$, 60, 75, 90, 105, and 120). Forage allowance was also calculated (McCartor \& Rouquette, 1977; Sollenberger, Moore, Allen, \& Pedreira, 2005) for each period as follows:

$$
\text { Forage allowance }=\text { Forage mass }(\mathrm{kg} / \mathrm{ha}) / \text { Animal } B W(\mathrm{~kg} / \mathrm{ha})
$$

\subsection{Statistical Analysis}

The experiment was a completely randomized design with three replicates. Data were analyzed with PROC GLM of SAS (version 9.4, SAS Inc., Cary, NC). Forage mass, height, growth, allowance, and nutritive value were analyzed for treatment, sampling date and their interaction. Productivity (beef produced/ha), grazing days, DMI, and ADG were analyzed for treatment, year, and their interaction. In all cases, paddock was the experimental unit and level of significance was set at $\alpha=0.05$.

\section{Results}

Weather conditions during the years of the experiment are presented in Table 1. When compared to historic values, Year 1 was 2 to 4 degrees Celsius colder (maximum and minimum temperature) from January to April with excessive rainfall in October and December while rainfall in January, March, April, and May were very low. Year 2 was very dry throughout the grazing season (December to May) and Year 3 was 2 to 5 degrees Celsius warmer (maximum and minimum temperatures) with variations in pattern of rainfall (drier December, wetter January, February, and April) when compared to historic values.

Table 1. Weather data (monthly averages for maximum and minimum temperatures and total rainfall) for the

\begin{tabular}{|c|c|c|c|c|c|c|c|c|c|c|c|c|}
\hline & \multicolumn{3}{|c|}{ Year 1} & \multicolumn{3}{|c|}{ Year 2} & \multicolumn{3}{|c|}{ Year 3} & \multicolumn{3}{|c|}{ HISTORIC $^{1}$} \\
\hline & $\operatorname{Max}^{2}$ & $\operatorname{Min}^{3}$ & Rain $^{4}$ & Max & Min & Rain & Max & Min & Rain & Max & Min & Rain \\
\hline $\mathrm{J}^{5}$ & 34.1 & 21.8 & 18.8 & 33.2 & 24.4 & 200.2 & 34.7 & 23.5 & 90.4 & 31.3 & 21.9 & 206.8 \\
\hline $\mathrm{J}$ & 33.6 & 23.9 & 204.7 & 33.3 & 24.5 & 255.5 & 33.2 & 24.3 & 180.3 & 32.2 & 22.8 & 176.3 \\
\hline A & 33.3 & 23.0 & 93.0 & 34.0 & 24.7 & 79.8 & 36.1 & 24.6 & 52.8 & 32.4 & 22.4 & 161.0 \\
\hline S & 31.1 & 22.0 & 147.6 & 32.7 & 21.7 & 71.6 & 31.2 & 19.1 & 190.2 & 30.4 & 19.9 & 163.8 \\
\hline $\mathrm{O}$ & 26.4 & 16.5 & 295.9 & 28.3 & 12.9 & 33.0 & 27.6 & 11.8 & 10.7 & 26.3 & 14.4 & 128.5 \\
\hline $\mathrm{N}$ & 21.8 & 9.2 & 26.4 & 22.7 & 10.0 & 173.7 & 23.4 & 10.2 & 96.5 & 21.7 & 9.9 & 99.8 \\
\hline D & 15.7 & 6.3 & 415.3 & 17.0 & 4.5 & 88.4 & 19.0 & 7.8 & 81.8 & 17.3 & 6.2 & 127.5 \\
\hline $\mathrm{J}$ & 14.7 & 3.1 & 39.4 & 15.9 & 4.2 & 97.8 & 20.8 & 9.3 & 152.1 & 16.1 & 5.2 & 123.2 \\
\hline $\mathrm{F}$ & 13.8 & 3.4 & 131.8 & 18.8 & 6.3 & 31.8 & 20.3 & 11.3 & 130.8 & 17.8 & 7.1 & 112.5 \\
\hline M & 19.7 & 7.5 & 16.8 & 24.7 & 12.4 & 68.6 & 26.5 & 15.2 & 83.8 & 21.4 & 10.4 & 99.8 \\
\hline A & 26.9 & 14.8 & 31.8 & 28.5 & 16.6 & 11.2 & 27.8 & 16.2 & 145.8 & 25.2 & 14.0 & 102.4 \\
\hline $\mathrm{M}$ & 31.5 & 20.8 & 59.7 & 30.6 & 18.8 & 9.7 & 31.5 & 19.9 & 50.5 & 28.8 & 18.6 & 111.3 \\
\hline
\end{tabular}
grazing seasons obtained at the Iberia Research Station and historical data for the previous 38 years

Note. ${ }^{1}$ HISTORIC: Historic weather data (1970-2008).

${ }^{2}$ Max: Average maximum monthly temperatures, Celsius.

${ }^{3}$ Min: Average minimum monthly temperatures, Celsius.

${ }^{4}$ Rain: Monthly rainfall, $\mathrm{mm}$.

${ }^{5}$ Months of the year, from J (June) to M (May) of the following year. 


\subsection{Forage Characteristics and Nutritive Value}

Annual ryegrass DM production and height at 15-d intervals throughout the grazing period for all treatments are presented in Tables 2 and 3. On d 60, forage mass and height were low in HIGH and heifers were removed from the pastures until enough regrowth was present, $30 \mathrm{~d}$ after. Similar decision, based on the same variables, was taken for MED stocking rate when heifers were removed on d 105, although in this case not enough regrowth was produced to include them again in the pastures. Noticeable, both groups of supplemented heifers had greater forage mass and height than MED and HIGH, although smaller than LOW. Nutritive value of annual ryegrass (Table 4) was, as expected, normal for a cool season grass: high in CP, TDN, and IVDMD, while low in NDF and ADF concentrations. As grazing season advances NDF and ADF increased with smaller values for TDN and IVDMD.

Table 2. Forage mass available (kg DM/ha) at $15 \mathrm{~d}$ intervals during the grazing season

\begin{tabular}{lllllll}
\hline \multirow{2}{*}{ Sampling day } & \multicolumn{5}{c}{ Treatment $^{1}$} \\
\cline { 2 - 5 } LOW & MED & HIGH & HIGH+C & HIGH+SBH \\
\hline 0 & 1,759 & 1,620 & 1,990 & 1,870 & 2,080 & 356 \\
15 & 1,580 & 1,325 & 1,409 & 1,540 & 1,369 & 214 \\
30 & 1,369 & 1,350 & 1,150 & 1,450 & 1,590 & 264 \\
45 & $1,258^{\mathrm{a}}$ & $1,098^{\mathrm{ab}}$ & $890^{\mathrm{b}}$ & $1,296^{\mathrm{a}}$ & $1,136^{\mathrm{a}}$ & 192 \\
60 & $1,044^{\mathrm{a}}$ & $991^{\mathrm{a}, \mathrm{b}}$ & $540^{\mathrm{b}}$ & $1,187^{\mathrm{a}}$ & $1,208^{\mathrm{a}}$ & 401 \\
75 & $2,238^{\mathrm{a}}$ & $1,963^{\mathrm{a}}$ & $795^{\mathrm{b}}$ & $1,764^{\mathrm{a}}$ & $2,044^{\mathrm{a}}$ & 283 \\
90 & $2,170^{\mathrm{a}}$ & $1,140^{\mathrm{b}}$ & $921^{\mathrm{b}}$ & $2,125^{\mathrm{a}}$ & $1,650^{\mathrm{a}}$ & 321 \\
105 & $2,876^{\mathrm{a}}$ & $740^{\mathrm{b}}$ & $1,135^{\mathrm{b}}$ & $2,347^{\mathrm{a}}$ & $1,947^{\mathrm{a}}$ & 512 \\
120 & $1,764^{\mathrm{a}}$ & $895^{\mathrm{b}}$ & $770^{\mathrm{b}}$ & $2,408^{\mathrm{a}}$ & $1,784^{\mathrm{a}}$ & 460 \\
\hline
\end{tabular}

Note. ${ }^{\text {a,b }}$ Least square means within a row, means without a common superscript letter differ $(P<0.05)$.

${ }^{1} \mathrm{LOW}=$ low stocking rate, 2.5 heifers per hectare; MED = medium stocking rate, 5 heifers per hectare; HIGH = high stocking rate, 7.5 heifers per hectare; $\mathrm{HIGH}+\mathrm{C}=$ high stocking rate $+1 \% \mathrm{BW}$ of ground corn; $\mathrm{HIGH}+\mathrm{SBH}$ $=$ high stocking rate $+1 \% \mathrm{BW}$ of soybean hulls.

Table 3. Forage height $(\mathrm{cm})$ at $15 \mathrm{~d}$ intervals during the grazing season

\begin{tabular}{lllllll}
\hline \multirow{2}{*}{ Sampling day } & \multicolumn{7}{c}{ Treatment $^{1}$} \\
\cline { 2 - 6 } & LOW & MED & HIGH & HIGH+C & HIGH+SBH & \\
\hline 0 & 19.2 & 21.9 & 22.7 & 20.8 & 20.0 & 2.9 \\
15 & 13.8 & 15.4 & 14.3 & 13.9 & 15.0 & 2.1 \\
30 & 15.2 & 15.0 & 13.5 & 14.2 & 14.2 & 3.6 \\
45 & 14.8 & 12.3 & 8.9 & 11.0 & 10.1 & 3.2 \\
60 & $16.2^{\mathrm{a}}$ & $10.6^{\mathrm{b}}$ & $4.2^{\mathrm{c}}$ & $9.9^{\mathrm{b}}$ & $12.0^{\mathrm{ab}}$ & 2.5 \\
75 & $15.2^{\mathrm{a}}$ & $9.8^{\mathrm{bc}}$ & $5.2^{\mathrm{c}}$ & $10.6^{\mathrm{ab}}$ & $11.0^{\mathrm{ab}}$ & 2.8 \\
90 & $12.8^{\mathrm{a}}$ & $10.6^{\mathrm{a}}$ & $6.1^{\mathrm{b}}$ & $9.2^{\mathrm{ab}}$ & $11.6^{\mathrm{a}}$ & 2.1 \\
105 & 11.4 & 5.1 & 10.2 & 10.8 & 9.1 & 3.3 \\
120 & 8.4 & 6.2 & 5.9 & 7.6 & 8.4 & 1.6 \\
\hline
\end{tabular}

Note. ${ }^{\text {a,b,c }}$ Least square means within a row, means without a common superscript letter differ $(P<0.05)$.

${ }^{1} \mathrm{LOW}=$ low stocking rate, 2.5 heifers per hectare; MED = medium stocking rate, 5 heifers per hectare; HIGH = high stocking rate, 7.5 heifers per hectare; $\mathrm{HIGH}+\mathrm{C}=$ high stocking rate $+1 \% \mathrm{BW}$ of ground corn; $\mathrm{HIGH}+\mathrm{SBH}$ $=$ high stocking rate $+1 \% \mathrm{BW}$ of soybean hulls. 
Table 4. Nutritive value characteristics (\% DM) of hand-plucked samples of annual ryegrass cv. 'Nelson' at $15 \mathrm{~d}$ intervals during the grazing season

\begin{tabular}{|c|c|c|c|c|c|}
\hline \multirow{2}{*}{ Sampling day } & \multicolumn{5}{|c|}{ Nutritive value, $\%$ DM } \\
\hline & $\mathrm{CP}$ & NDF & $\mathrm{ADF}$ & TDN & IVDMD \\
\hline 0 & $23.4^{b}$ & $31.0^{\mathrm{e}}$ & $18.5^{\mathrm{c}}$ & $77.1^{\mathrm{a}}$ & $82.4^{\mathrm{a}}$ \\
\hline 15 & $19.6^{\mathrm{bc}}$ & $33.9^{\mathrm{d}}$ & $20.4^{\mathrm{c}}$ & $74.6^{\mathrm{ab}}$ & $78.5^{\mathrm{b}}$ \\
\hline 30 & $22.3^{\mathrm{b}}$ & $39.8^{\mathrm{c}}$ & $25.6^{\mathrm{b}}$ & $69.9^{c}$ & $74.6^{\mathrm{c}}$ \\
\hline 45 & $23.1^{\mathrm{b}}$ & $42.5^{\mathrm{b}}$ & $25.9^{\mathrm{b}}$ & $72.9^{\mathrm{b}}$ & $77.2^{\mathrm{b}}$ \\
\hline 60 & $27.5^{\mathrm{a}}$ & $44.4^{\mathrm{b}}$ & $24.0^{\mathrm{b}}$ & $64.9^{\mathrm{d}}$ & $74.3^{\mathrm{c}}$ \\
\hline 75 & $22.8^{\mathrm{b}}$ & $46.2^{\mathrm{b}}$ & $26.3^{\mathrm{b}}$ & $69.1^{\mathrm{c}}$ & $74.5^{\mathrm{c}}$ \\
\hline 90 & $20.7^{\mathrm{b}}$ & $53.9^{\mathrm{a}}$ & $32.5^{\mathrm{a}}$ & $72.1^{b}$ & $72.0 \mathrm{c}$ \\
\hline 105 & $19.1^{\mathrm{bc}}$ & $54.8^{\mathrm{a}}$ & $33.9^{\mathrm{a}}$ & $68.9^{c}$ & $70.1^{\mathrm{d}}$ \\
\hline 120 & $18.2^{\mathrm{c}}$ & $56.7^{\mathrm{a}}$ & $33.7^{\mathrm{a}}$ & $69.9^{c}$ & $62.9^{\mathrm{e}}$ \\
\hline SEM & 0.71 & 0.58 & 0.60 & 0.71 & 0.51 \\
\hline
\end{tabular}

Note. ${ }^{\text {a-e }}$ Within a column, means without a common superscript letter differ $(P<0.05)$.

\subsection{Dry Matter Intake and Animal Performance}

Rate of DM production of annual ryegrass (Table 5) reflects the normal trend in terms of the growth habit for cool-season grasses: greater rates early and late in the grazing season with a pronounced dip in the middle of the winter season. This, in turn, follows a similar pattern for forage allowance (Table 5). Average body weight $(\mathrm{kg})$ changes of replacement heifers during the experimental periods are shown in Figure 1. Heifers in MED and HIGH were removed from the pastures on d 105 and 60, respectively. Heifers in HIGH were returned to their respective pastures on $\mathrm{d} 90$ until the end of the grazing period (d 120).

Table 5. Least square means for forage growth and allowance by grazing period

\begin{tabular}{llllllllll}
\hline \multirow{2}{*}{ Item } & \multicolumn{10}{c}{ Periods $^{1}$} & \multicolumn{1}{c}{ SEM } \\
\cline { 2 - 10 } & 1 & 2 & 3 & 4 & 5 & 6 & 7 & 8 \\
\hline Daily Forage growth, kg DM/ha & $120.2 \mathrm{ab}$ & $116.8 \mathrm{ab}$ & $111.6 \mathrm{ab}$ & $92.9 \mathrm{~b}$ & $82.9 \mathrm{~b}$ & $107.0 \mathrm{ab}$ & $169.8 \mathrm{a}$ & $159.1 \mathrm{a}$ & 31.8 \\
Forage allowance, $\mathrm{kg} \mathrm{DM} / \mathrm{kg} \mathrm{BW}^{2}$ & $1.32 \mathrm{a}$ & $1.08 \mathrm{ab}$ & $0.93 \mathrm{~b}$ & $0.76 \mathrm{~b}$ & $1.14 \mathrm{ab}$ & $1.40 \mathrm{a}$ & $1.44 \mathrm{a}$ & $1.32 \mathrm{a}$ & 0.19 \\
\hline
\end{tabular}

Note. ${ }^{\mathrm{a}-\mathrm{d}}$ Within a row, means without a common superscript letter differ $(P<0.05)$.

${ }^{1}$ Periods are: 1 (d 0 to 15 ), 2 (d16 to 30), 3 (d 31 to 45), 4 (d 46 to 60), 5 (d 61 to 75), 6 (d 76to 90), 7 (d 91 to105), 8 (d 106 to 120$)$.

${ }^{2}$ Exclude HIGH stocking rate in periods 5, 6, and 7, and MED stocking rate in period 8 since heifers were not grazing the experimental pastures due to lack of forage.

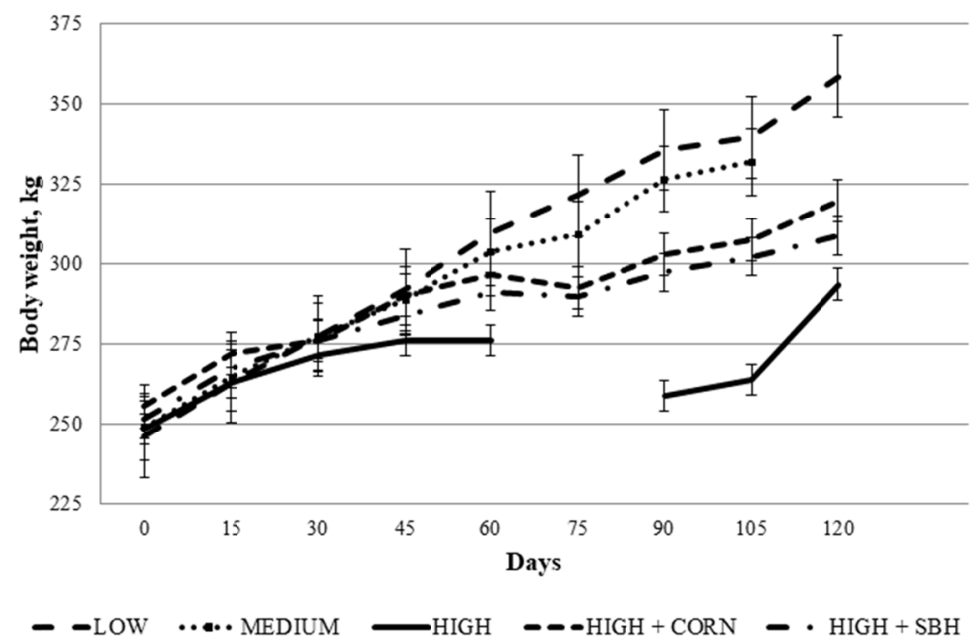

Figure 1. Body weight (kg) of replacement heifers throughout the experimental period (d 0 to 120 ) 
There were treatment and year effects but no interactions on DM production, DMI, and animal performance (Tables 6 and 7). Dry matter intake (expressed as \% BW and $\mathrm{kg} \mathrm{DM} / \mathrm{d})$ from annual ryegrass was greater $(P=$ 0.03 ) for heifers in LOW and MED, while those in HIGH, regardless of supplemented or no supplemented, were the lowest (Table 6). No differences $(P=0.81)$ in supplement DM intake was observed between $\mathrm{HIGH}+\mathrm{C}$ and $\mathrm{HIGH}+\mathrm{SBH}$. When adding the DMI from corn and soybean hulls in the supplemented treatments to the DMI from annual ryegrass, total DMI $(\mathrm{kg} / \mathrm{d})$ was smallest $(P=0.001)$ for HIGH and not significantly different $(P>$ $0.05)$ between the other treatments. Heifers grazing LOW and MED did not differ $(P=0.06)$ in ADG, but heifers in LOW had greater gains than heifers in the other treatments (Table 6). Heifers in LOW produced the least per unit of land although it was similar to HIGH. Supplemented heifers and those in MED produced the most beef per hectare, although MED and HIGH were not significantly different. Grazing days was greater for LOW and supplemented heifers while MED was intermediate and HIGH had the shortest grazing period (Table 6). Animal performance (ADG and beef production) and grazing days were smaller in Year 1 (Table 7). Years 2 and 3 were not different $(P>0.05)$ between them in any of the variables (Table 7) except in beef production per hectare (449.7 vs. $513.3 \mathrm{~kg} / \mathrm{ha}$, respectively).

Table 6. Least square means for annual ryegrass production, dry matter intake, and production performance

\begin{tabular}{|c|c|c|c|c|c|c|c|}
\hline \multirow{2}{*}{ Item } & \multicolumn{3}{|c|}{ Year } & \multirow{2}{*}{ SEM } & \multicolumn{3}{|c|}{$P$-value } \\
\hline & 1 & 2 & 3 & & Treatment & Year & Treatment $\times$ Year \\
\hline Forage mass, $\mathrm{kg} \mathrm{DM} / \mathrm{ha}$ & $1081^{b}$ & $1314^{\mathrm{ab}}$ & $1407^{\mathrm{a}}$ & 158 & $<0.001$ & 0.01 & 0.12 \\
\hline Forage DMI, \%BW & $1.45^{\mathrm{b}}$ & $1.72^{\mathrm{a}}$ & $1.61^{\mathrm{ab}}$ & 0.10 & 0.007 & 0.03 & 0.08 \\
\hline $\mathrm{ADG}, \mathrm{kg}$ & $0.61^{\mathrm{b}}$ & $0.83^{\mathrm{a}}$ & $1.01^{\mathrm{a}}$ & 0.21 & 0.02 & 0.04 & 0.06 \\
\hline Beef production, $\mathrm{kg} / \mathrm{ha}$ & $389.2^{\mathrm{c}}$ & $449.7^{\mathrm{b}}$ & $513.3^{\mathrm{a}}$ & 22.5 & 0.001 & 0.002 & 0.11 \\
\hline Grazing days & $94.1^{\mathrm{b}}$ & $104.7^{\mathrm{a}}$ & $111.4^{\mathrm{a}}$ & 5.7 & $<0.0001$ & 0.001 & 0.09 \\
\hline
\end{tabular}

Table 7. Least square means for daily forage dry matter intake (as \% BW and $\mathrm{kg} \mathrm{DM}$ ), ADG, and production per hectare

\begin{tabular}{|c|c|c|c|c|c|c|}
\hline \multirow{2}{*}{ Item } & \multicolumn{5}{|c|}{ Treatment $^{1}$} & \multirow{2}{*}{ SEM } \\
\hline & LOW & MED & HIGH & $\mathrm{HIGH}+\mathrm{C}$ & $\mathrm{HIGH}+\mathrm{SBH}$ & \\
\hline \multicolumn{7}{|l|}{ Annual ryegrass } \\
\hline DMI, \% BW & $2.41^{\mathrm{a}}$ & $1.95^{\mathrm{a}}$ & $0.96^{\mathrm{b}}$ & $1.12^{\mathrm{b}}$ & $1.29^{\mathrm{b}}$ & 0.36 \\
\hline DMI, $\mathrm{kg} \mathrm{DM} / \mathrm{d}^{2}$ & $7.34^{\mathrm{a}}$ & $5.73^{\mathrm{a}}$ & $2.55^{\mathrm{b}}$ & $3.25^{\mathrm{b}}$ & $3.68^{\mathrm{b}}$ & 1.21 \\
\hline \multicolumn{7}{|l|}{ Supplement } \\
\hline DMI, \% BW & - & - & - & 0.98 & 1.02 & 0.02 \\
\hline DMI, kg DM/head/d & - & - & - & 3.05 & 2.99 & 0.09 \\
\hline Total DMI, kg/d & $7.34^{\mathrm{a}}$ & $5.73^{\mathrm{a}}$ & $2.55^{\mathrm{b}}$ & $6.30^{\mathrm{a}}$ & $6.67^{\mathrm{a}}$ & 0.96 \\
\hline ADG, $\mathrm{kg}$ & $1.08^{\mathrm{a}}$ & $0.87^{\mathrm{ab}-1}$ & $0.57^{\mathrm{c}-}$ & $0.61^{\mathrm{bc}^{-}}$ & $0.58^{\mathrm{bc}-1}$ & 0.19 \\
\hline Beef produced, $\mathrm{kg} / \mathrm{ha}$ & $318.6^{\mathrm{c}}$ & $443.5^{\mathrm{ab}}$ & $375.6^{\mathrm{bc}}$ & $542.2^{\mathrm{a}}$ & $512.1^{\mathrm{a}}$ & 55.8 \\
\hline Grazing days & $120^{\mathrm{a}}$ & $101^{\mathrm{b}}$ & $89^{c}$ & $118^{\mathrm{a}}$ & $118^{\mathrm{a}}$ & 8 \\
\hline
\end{tabular}

Note. ${ }^{\mathrm{a}, \mathrm{b}, \mathrm{c}}$ Least square means within a row, means without a common superscript letter differ $(P<0.05)$.

${ }^{1} \mathrm{LOW}=$ low stocking rate, 2.5 heifers per hectare; MED = medium stocking rate, 5 heifers per hectare; $\mathrm{HIGH}=$ high stocking rate, 7.5 heifers per hectare; $\mathrm{HIGH}+\mathrm{C}=$ high stocking rate $+1 \% \mathrm{BW}$ of ground corn; $\mathrm{HIGH}+\mathrm{SBH}$ $=$ high stocking rate $+1 \% \mathrm{BW}$ of soybean hulls.

${ }^{2}$ Estimations of DMI for MED and HIGH do not include periods where heifers were not grazing.

\section{Discussion}

Most annual ryegrass cultivars released before 1985 (i.e., 'Gulf', 'Marshall', among others) were diploid. In the last two decades, new cultivars categorized as tetraploid have been developed ('Jumbo', 'Nelson', 'Prine', among others). Main attributes of 'Nelson' (Nelson, Crowder, \& Rouquette, 2011) are a large plant stature compared to diploid cultivars, provides greater forage yield potential, good crown rust resistance, and a wide range in adaptability across southern United States. Very little information is available regarding the use of 'Nelson' cultivar under grazing conditions. This manuscript is one of the first published. 
In general, stocking rate is more important than stocking method with respect to production efficiency and economic returns (Rouquette \& Smith, 2010). Input costs, especially for fertilizer and supplementation, and the absolute price of stocker cattle as well as the purchase-sell margins vary by year, location, and animal factors (Rouquette \& Smith, 2010). Determining stocking rates requires knowledge of forage production and grazing pressure. Stocking rate clearly affected annual ryegrass availability and height. At d 45 of the grazing period heifers in HIGH had already limited amount of annual ryegrass (below 1,000 kg DM/ha and $10 \mathrm{~cm}$ of height) and $15 \mathrm{~d}$ later they were moved out of the pasture due to lack of forage, variables that were negatively affecting animal performance. Coffey et al. (2002) reported that forage mass ranged from 403 to 2,902 $\mathrm{kg} \mathrm{DM} / \mathrm{ha}$, with a mean forage mass of $1,341 \mathrm{~kg} \mathrm{DM} / \mathrm{ha}$ when winter wheat (Triticum aestivum) and ryegrass were stocked continuously over a 3-yr trial. In addition, Mader, Horn, Phillips, and McNew (1983) reported that the forage mass of continuously stocked winter wheat pastures ranged from 365 to $1,664 \mathrm{~kg} \mathrm{DM} / \mathrm{ha}$, with a mean forage mass of $838 \mathrm{~kg} \mathrm{DM} / \mathrm{ha}$. In the present experiment, forage mass was within a range between 540 to $2,876 \mathrm{~kg}$ $\mathrm{DM} / \mathrm{ha}$; however, HIGH treatment just varied between 540 (d 60) and 1,990 (d 0) $\mathrm{kg} \mathrm{DM} / \mathrm{ha}$. Scaglia et al. (2009a) evaluated the effect of time of supplementation on steers with similar BW than the heifers in the present study and continuously stocked at 4.5 steers/ha, a small difference in stocking rate than MED. Annual ryegrass available throughout the grazing season followed a similar in pattern in the non-supplemented treatment (Scaglia et al., 2009a) and in MED of the present experiment. Smaller availability was present on d 60 followed later on by greater availability due to favorable spring conditions.

Despite the lower rates of $\mathrm{N}$ application in the present experiment, nutritive value of annual ryegrass was similar to those previously reported by Hafley (1996) but smaller than Scaglia et al. (2009b). Notably, the latter work used three split applications of urea adding nearly twice the $\mathrm{N}$ compared to the present experiment. Nutritive value characteristics are sufficient to cover the requirements of growing beef cattle (NASEM, 2016). Data for IVDMD were greater than those reported by Hafley (1996) which were between 68 and 70\%; however Hafley (1996) evaluated 'Marshall' ryegrass, a diploid variety. These differences may have been due, in part, to the use of an improved cultivar such as 'Nelson' (a tetraploid).

Supplementation at high stocking rates is a common practice to maintain greater number of animals and simultaneously stretching forage availability for a longer period of time. By-product feeds that have high TDN $(>75 \%$ TDN in DM) and low non-structural carbohydrates or NSC $(<30 \%$ NSC in DM) include soybean hulls (SBH), wheat middlings, corn gluten feed, beet pulp, citrus pulp, distillers grains, and brewers grains (Kunkle et al., 2000). Soybean hulls, a by-product of soybean processing, are nearly balanced in protein (12 to 14\%), calcium $(0.63 \%)$, and phosphorus $(0.23 \%)$ for supplementing beef cattle (NASEM, 2016). They are palatable and the risk of acidosis is low; consequently, this commodity feed is often fed without blending with other ingredients. Several trials evaluated similar quantities of corn balanced with protein and SBH supplements on gains of growing cattle, and reported gains were similar for levels ranging from 0.4 to $1.0 \% \mathrm{BW}$ (McDonnell, Klopfenstein, \& Merrill, 1982; Anderson, Merrill, \& Klopfenstein, 1988a; Anderson, Merrill, McDonnell, \& Klopfenstein, 1988b; Brown \& Weigel, 1993); one trial reported a 10\% increase in gains (Anderson et al., 1988b). Two trials evaluated similar levels of supplemental TDN from corn or SBH and reported similar cattle gains when levels were below $0.5 \% \mathrm{BW}$, but 10 to $25 \%$ improvements in gains, for corn, when feeding at $1 \%$ BW (Heird, Goetsh, Brown Jr., Lewis, \& Johnson, 1994; Garcés-Yepez et al., 1997). Studies comparing cornprotein and SBH supplementation effects on forage intake and digestibility suggest advantages for SBH, especially when fed at levels above $0.5 \%$ BW. Provision of moderate amounts of energy supplements to growing cattle on high quality pastures, like annual ryegrass, is of particular importance because of the potentially large fluctuations in amounts of available forage. The response of growing cattle on wheat and/or other small grain pastures to supplemental grain has been variable. In studies reported by Lowrey, Calvert, McCampbell, and Woods (1976a), Lowrey, McCampbell, Calvert, Beaty, and Woods (1976b), Utley and McCormick (1975, 1976), and Gulbransen (1976), steer grazing days per hectare or stocking densities were increased 1.25- to 2-fold and daily gains were increased by 0.05 to $0.30 \mathrm{~kg}$ by feeding grain at levels of 1 to $1.5 \%$ of $\mathrm{BW}$. In the present experiment, the use of a high level of supplementation (1\% BW) with SBH or corn helped maintaining heifers on pasture, however, their forage DMI was not different from HIGH performance. Heifers on LOW and MED had greater annual ryegrass DMI, while heifers in HIGH had the lowest in total DMI (forage + supplement). By design, supplemented treatments received $1 \% \mathrm{BW}$ of supplement which turned up to be close to $50 \%$ of their daily DMI. Despite these high levels of supplementation, ADG were smaller than LOW, although beef production per unit of area were greater than for the non-supplemented treatments. One hypothesis is that the high level of supplementation may have caused a drop in ruminal $\mathrm{pH}$ affecting DMI. Energy supplements may have different effects on ruminal $\mathrm{pH}$ depending on the feedstuff composition of the supplement, the form and type of forage, the resulting rate of particle fragmentation as well as the buffering capacity of ruminal fluid per 
se; however, ground corn or a highly digestible fiber such as $\mathrm{SBH}$, are known sources causing negative effects on fiber digestibility, leading to acidosis, and reduction of dry matter intake (Horn \& McCollum, 1987). The effects of readily fermentable carbohydrate to reduce rumen DM digestibility of forages have been linearly related to their content of NDF (Dixon \& Parra, 1984; Dixon, 1986).

Bagley and DeRamus (1984) working in a very similar environment indicated that in Louisiana there is a low forage production in the fall and winter, followed by a peak of forage yield in the spring. In the present experiment, forage DM production followed a bimodal curve, as reported previously (Bagley, Feazel, \& Carpenter Jr., 1982; Bagley, Feazel, \& Koonce, 1988; Feazel, 1986; Rouquette, Bransby, \& Riewe, 1997; Vendramini \& Arthington, 2008). According to Redfearn, Venuto, Pitman, Alison, and Ward (2002), 30-40\% of the total forage production from annual ryegrass cultivars occurs from December to February, while the remaining $60 \%$ occurring from March to May. The definition of forage allowance (weight of forage mass per $\mathrm{kg}$ of animal BW) integrates forage mass and stocking rate (Hodgson, 1979). The relationship between forage allowance and animal performance for a particular forage type has potential application across a broader range of environments and situations than relationships of animal performance versus either forage mass or stocking rate (Sollenberger et al., 2005). Because of greater forage mass and lower heifers BW, period 1 had the greater forage allowance, gradually declining until period 4 to start increasing again from period 5 to 7 . Period 8 presented a similar forage allowance than at the beginning of the grazing period. These results contradict those presented by Scaglia et al. (2009b) who reported a constant declined in forage allowance throughout the grazing period. This difference is mainly explained by the differences in ADG of the experimental animals. Heifers in the present experiment regardless of treatment had smaller ADG (1.08 to $0.57 \mathrm{~kg} / \mathrm{d}$; Figure 1; Table 7) while steers in the experiment reported by Scaglia et al. (2009a) varied from 1.14 to $1.34 \mathrm{~kg} / \mathrm{d}$. When compared similar stocking rates between these two experiments, heifers in MED gained approximately $70 \%(0.87 \mathrm{~kg} / \mathrm{d})$ of the steers' gain $(1.2 \mathrm{~kg} / \mathrm{d})$. Most of this difference might be due to the fact that heifers gained less than steers as reported elsewhere (Gross, Goode, Gilbert, \& Ellis, 1966; Rouquette Jr., Griffin, Randel, \& Carroll, 1980; Lowman, Hinks, Hunter, \& Scott, 1996) but there was also a clear difference in weather conditions (year effect). Heifers in LOW reached an appropriate breeding weight of $355 \mathrm{~kg}$ and those in MED were borderline at $330 \mathrm{~kg}$. Beef heifers should be managed to achieve puberty early, conceive early in the first breeding season, calve unassisted, and breed back early for their second calf (Wiltbank et al., 1966; Funston \& Deutscher, 2004). Traditionally, the recommendation has been that heifers be developed to reach 60 to $65 \%$ of mature BW by the onset of the breeding season (Patterson et al., 1992). However, recent research has demonstrated heifers reaching less than $58 \%$ of mature BW by breeding do not display impaired reproductive performance (Funston \& Deutscher, 2004; Funston, Martin, Larson, \& Roberts, 2012). In our conditions, Brahman influenced heifers required at least $65 \%$ of mature BW (Scaglia, unpublished data). The amount of forage available for harvest is affected by climate, soil characteristics (depth, slope, and texture), and the extent of unproductive areas where rocks, brush, and unpalatable species are prevalent. Of these factors, climate has the most significant and overriding influence on forage production (Ohlenbusch \& Watson, 1994). It has been clearly demonstrated in annual ryegrass that grazing management and weather conditions have a great impact on DM production and animal performance (Rouquette et al., 1997). The effect of weather conditions on forage and animal production was clearly observed. Excessive precipitation (Table 1) and cloudiness (data not shown) in year 1, affected dry matter production during the annual ryegrass fall growing period. This affected the total DM production for the grazing season which in turns affected grazing days and heifers' performance. Year 2 was drier than year 1 and year 3 but annual ryegrass productivity was similar to the latter, although more beef production per hectare was obtained in year 3 (Table 6).

In the conditions of the present experiment supplementation with ground corn or soybean hulls at $1 \%$ of the heifers' BW did not improve their growth and negatively affected DMI from annual ryegrass; in fact heifers grazing at low stocking rates were able to develop their individual genetic potential and reach an appropriate BW at breeding. Weather conditions present in the present study were very variable from year to year, reflected in differences in forage production across years. Adjustments in level of supplementation are critical for appropriate animal performance, forage utilization and profitability.

\section{Acknowledgements}

The author would like to thank the field personnel at the Iberia Research Station for their constant caring of the experimental animals. 


\section{References}

Anderson, S. J., Merrill, J. K., \& Klopfenstein, T. J. (1988a). Soybean hulls as an energy supplement for the grazing ruminant. Journal of Animal Science, 66, 2959-2964. https://doi.org/10.2527/jas1988.66112959x

Anderson, S. J., Merrill, J. K., McDonnell, M. L., \& Klopfenstein, T. J. (1988b). Digestibility and utilization of mechanically processed soybean hulls by lambs and steers. Journal of Animal Science, 66, 2965-2976. https://doi.org/10.2527/jas1988.66112965x

Ankom Technology. (1997a). In Vitro True Digestibility Using the Daisy II Incubator. Ankom Technology Corp., Fairport, NY.

Ankom Technology. (1997b). Methods for Determining Neutral Detergent Fiber. Ankom Technology Corp., Fairport, NY.

Association of Official Analytical Chemists. (2000). Official Methods of Analysis (17th ed.). Assoc. Off. Anal. Chem. Gaithersburg, MD.

Bagley, C. P., Feazel, J. I., \& Carpenter Jr., J. C. (1982). Grazing steers on winter annuals (p. 56). Louisiana Agriculture Experiment Station Report 26. Louisiana Agriculture Experiment Station, Rosepine.

Bagley, C. P., \& DeRamus, H. A. (1984). Forage mixtures of oats, rye, and wheat planted with ryegrass and arrowleaf clover for grazing beef steers (p. 120). Annual Research Report Rosepine Research Station. Louisiana Agriculture Experiment Station, Louisiana State University Agricultural Center, Baton Rouge.

Bagley, C. P., Feazel, J. I., \& Koonce, K. L. (1988). Cool-season annual forage mixtures for grazing beef steers. Journal of Production Agriculture, 1, 149-152. https://doi.org/10.2134/jpa1988.0149

Brown, W. F., \& Weigel, J. (1993). Utilization of soybean hulls in supplemental programs for beef cattle (pp. 76-89). Proceedings of the 4th Annual Florida Ruminant Nutrition Symposium, University of Florida, Gainesville.

Coffey, K. P., Coblentz, W. K., Montgomery, T. G., Shockey, J. D., Bryant, K. J., Francis, P. B., Rosenkrans Jr., C. F., \& Gunter, S. A. (2002). Growth performance of stocker calves backgrounded on sod-seeded winter annuals or hay and grain. Journal of Animal Science, 80, 926-932. https://doi.org/10.2527/2002.804926x

Dixon, R. M. (1986). Effects of dietary concentrates on rumen digestion of fibrous feedstuffs. Animal Feed Science and Technology, 14, 193-202. https://doi.org/10.1016/0377-8401(86)90092-1

Dixon, R. M., \& Parra, R. (1984). Effects of alkali treatment of forage and concentrate supplementation on rumen digestion and fermentation. Tropical Animal Production, 9, 68-80.

Dixon, R. M., \& Stockdale, C. R. (1999). Associative effects between forages and grains: Consequences for feed utilization. Australian Journal of Agricultural Research, 50, 757-773. https://doi.org/10.1071/AR98165

Feazel, J. I. (1986). Beef calf performance on overseeded winter annual pastures (pp. 131-134). Louisiana Experimental Station Progress Report 86-1. Louisiana Agriculture Experimental Station.

Forage and Grazing Terminology Committee. (1991). Terminology for grazing lands and grazing animals. Pocahontas Press, Inc. Blacksburg, VA.

Funston, R. N., \& Deutscher, G. H. (2004). Comparison of target breeding weight and breeding date for replacement beef heifers and effects on subsequent reproduction and calf performance. Journal of Animal Science, 82, 3094-3099. https://doi.org/10.2527/2004.82103094x

Funston, R. N., Martin, J. L., Larson, D. M., \& Roberts, A. J. (2012). Physiology and endocrinology symposium: Nutritional aspects of developing replacement heifers. Journal of Animal Science, 90, 1166-1171. https://doi.org/10.2527/jas.2011-4569

Garcés-Yepez, P., Kunkle, W. E., Bates, D. B., Moore, J. E., Thatcher, W. W., \& Sollenberger, L. E. (1997). Effects of supplemental energy source and amount on forage intake and performance by steers and intake and diet digestibility by sheep. Journal of Animal Science, 75, 1918-1925. https://doi.org/10.2527/1997. $7571918 \mathrm{x}$

Grigsby, K. N., Kerley, M. S., Paterson, J. A., \& Weigel, J. C. (1993). Combinations of starch and digestible fiber in supplements for steers consuming low-quality bromegrass hay diet. Journal of Animal Science, 71, 1057-1064. https://doi.org/10.2527/1993.7141057x

Gross, H. D., Goode, L., Gilbert, W. B., \& Ellis, G. L. (1966). Beef grazing systems in Piedmont North Carolina. Agronomy Journal, 58(3), 307-310. https://doi.org/10.2134/agronj1966.00021962005800030019x 
Gulbransen, B. (1976). Response to supplementary sorghum grain by cattle grazing oats. Australian Journal of Experimental Agriculture and Animal Husbandry, 16, 646-653. https://doi.org/10.1071/EA9760646

Hafley, J. L. (1996). Comparison of Marshall and Surrey ryegrass for continuous and rotational grazing. Journal of Animal Science, 74, 2269-2275. https://doi.org/10.2527/1996.7492269x

Heird, C. E., Goetsh, A. L., Brown Jr., A. H., Lewis, P. K., \& Johnson, Z. B. (1994). Different supplements for steers consuming low quality forage. Professional Animal Scientist, 10, 112-117. https://doi.org/10.1523 2/S1080-7446(15)31953-7

Hodgson, J. (1979). Nomenclature and definitions in grazing studies. Grass and Forage Science, 34, 11-18. https://doi.org/10.1111/j.1365-2494.1979.tb01442.x

Horn, G. W., \& McCollum, F. T. (1987). In M. B. Judkins, D. C. Clanton, M. K. Petersen, \& J. D. Wallace (Eds.), Energy supplementation of grazing ruminants (pp. 125-130). Proceedings of the 1st Grazing Livestock Nutrition Conference, Jackson, WY.

Kennedy, D. W., \& Bunting, L. D. (1992). Effects of starch on ruminal fermentation and detergent fibre digestion in lambs fed bermudagrass hay. Animal Feed Science and Technology, 36, 91-100. https://doi.org/10.1016/ 0377-8401(92)90089-O

Kunkle, W. E., Johns, J. T., Poore, M. H., \& Herd, D. B. (2000). Designing supplementation programs for beef cattle fed forage-based diets. Journal of Animal Science, 77, 1-11. https://doi.org/10.2527/jas2000.00 218812007700ES0012x

Lowman, B. G., Hinks, C. E., Hunter, E. A., \& Scott, N. A. (1996). Effect of breed type, sex, method of rearing and winter nutrition on lifetime performance and carcass composition in a 20-month beef system: Grazing performance. Animal Science, 63(2), 215-222. https://doi.org/10.1017/S1357729800014764

Lowrey, R. S., Calvert, G. V., McCampbell, H. C., \& Woods, F. (1976a). Finishing weanling steers on winter pasture with or without grain. Journal of Animal Science, 42, 260.

Lowrey, R. S., McCampbell, H. C., Calvert, G. V., Beaty, E., \& Woods, F. (1976b). Effect of previous treatment and energy levels on finishing yearling steers on winter pasture. Journal of Animal Science, 42, 260.

Maas, J. (1987). Relationship between nutrition and reproduction in beef cattle. Veterinary Clinics of North America: Food Animal Practice, 3, 633-646. https://doi.org/10.1016/S0749-0720(15)31135-X

Mader, T. L., Horn, G. W., Phillips, W. A., \& McNew, R. W. (1983). Low quality roughages for steers grazing wheat pasture: Effect on weight gains and bloat. Journal of Animal Science, 56, 1021-1028. https://doi.org/ $10.2527 / \mathrm{jas} 1983.5651021 \mathrm{x}$

McCartor, M. M., \& Rouquette Jr., F. M. (1977). Grazing pressures and animal performance from pearl millet. Agronomy Journal, 69, 983-987. https://doi.org/10.2134/agronj1977.00021962006900060020x

McDonnell, M. L., Klopfenstein, T. J., \& Merrill, J. K. (1982). Soybean hulls as energy source for ruminants (pp. 54-56). Nebraska Beef Cattle Rep. MP-43. University of Nebraska, Lincoln.

Meyer, A. M., Kerley, M. S., \& Kallenbach, R. L. (2008). The effect of residual feed intake classification on forage intake by grazing beef cows. Journal of Animal Science, 86, 2670-2679. https://doi.org/10.2527/ jas.2007-0642

Mott, G. O. (1960). Grazing pressure and the measurement of pasture production (pp. 606-611). Proceedings of the 8th International Grassland Congress, Surfers Paradise, Australia.

National Academies of Sciences, Engineering, and Medicine. (2016). Nutrient Requirements of Beef Cattle (8th ed.). Washington, DC: The National Academies Press.

Nelson, L. R., Crowder, J., \& Rouquette, F. M. (2011). Registration of 'Nelson' Annual Ryegrass. Journal of Plant Registrations Abstract-CULTIVARS, 5(1), 45-48. https://doi.org/10.3198/jpr2010.02.0094crc

Ohlenbusch, P. D., \& Watson, S. L. (1994). Stocking rate and grazing management. Dept. of Agronomy, Kansas State University.

Patterson, D. J., Perry, R. C., Kiracofe, G. H., Bellows, R. A., Staigmiller, R. B., \& Corah, L. R. (1992). Management considerations in heifer development and puberty. Journal of Animal Science, 70, 4018-4035. https://doi.org/10.2527/1992.70124018x

Rearte, D. H., \& Pieroni, G. A. (2001). Supplementation of temperate pastures (pp. 679-689). Proceedings of the XIX International Grasslands Congress, Sao Pablo, Brazil. 
Redfearn, D. D., Venuto, B. C., Pitman, W. D., Alison, M. W., \& Ward, J. D. (2002). Cultivar and environment effects on annual ryegrass forage yield, yield distribution, and nutritive value. Crop Science, 42, 2049-2054. https://doi.org/10.2135/cropsci2002.2049

Roberts, A. J., Nugent, III, R. A., Klindt, J., \& Jenkins, T. G. (1997). Circulating insulin-like growth factor I, insulin-like growth factor binding proteins, growth hormone, and resumption of estrus in postpartum cows subjected to dietary energy restriction. Journal of Animal Science, 75, 1909-1917. https://doi.org/10.2527/ 1997.7571909x

Rouquette Jr., F. M., Griffin, J. L., Randel, R. D., \& Carroll, L. H. (1980). Effect of monensin on gain and forage utilization by calves grazing bermudagrass. Journal of Animal Science, 51(3), 521-525. https://doi.org/ 10.2527 jas $1980.513521 \mathrm{x}$

Rouquette, F. M. Jr., Bransby, D. I., \& Riewe, M. E. (1997). Grazing management and use of ryegrass. In F. M. Rouquette Jr. \& L. R. Nelson (Eds.), Ecology, Production, and Management of Lolium for Forage in the USA (CSSA Spec. Publication No. 24, pp. 79-99). American Society of Agronomy, Crop Science Society of America, Soil Science Society of America, Madison, WI. https://doi.org/10.2135/cssaspecp ub24.c6

Rouquette Jr., F. M., \& Smith, G. R. (2010). Review: Effects of biological nitrogen fixation and nutrient cycling on stocking strategies for cow-calf and stocker programs. Professional Animal Scientist, 26, 131-141. https://doi.org/10.15232/S1080-7446(15)30572-6

Sanderson, M. A., Rotz, C. A., Fultz, S. W., \& Rayburn, E. B. (2001). Estimating forage mass with a commercial capacitance meter, rising plate meter, and pasture ruler. Agronomy Journal, 93, 1281-1286. https://doi.org/ 10.2134/agronj2001.1281

Scaglia, G., Gillespie, J. M., Boland, H. T., \& Wyatt, W. E. (2009a). Effects of time of supplementation on beef stocker calves grazing ryegrass. I. Performance and economic analysis. Professional Animal Scientist, 25, 737-748. https://doi.org/10.15232/S1080-7446(15)30783-X

Scaglia, G., Boland, H. T., \& Wyatt, W. E. (2009b). Effects of time supplementation on beef stocker calves grazing ryegrass. II. Grazing behavior and dry matter intake. Professional Animal Scientist, 25, 749-756. https://doi.org/10.15232/S1080-7446(15)30784-1

Schillo, K. K., Hall, J. B., \& Hileman, S. M. (1992). Effects of nutrition and season on the onset of puberty in the beef heifer. Journal of Animal Science, 70, 3994-4005. https://doi.org/10.2527/1992.70123994x

Sollenberger, L. E., Moore, J. E., Allen, V. G., \& Pedreira, C. G. S. (2005). Reporting forage allowance in grazing experiments. Crop Science, 45, 896-900. https://doi.org/10.2135/cropsci2004.0216

Utley, P. R., \& McCormick, W. C. (1975). Dry or high-moisture corn for finishing steers in drylot or on oat pasture. Journal of Animal Science, 41, 495-502. https://doi.org/10.2527/jas1975.412495x

Utley, P. R., \& McCormick, W. C. (1976). Corn or grain sorghum for finishing steers in drylot or on rye pasture. Journal of Animal Science, 43, 1141-1150. https://doi.org/10.2527/jas1976.4361141x

Van der Linden, Y., Van Gylswyk, N. O., \& Schwartz, H. M. (1984). Influence of supplementation of corn stover with corn grain on the fibrolytic bacteria in the rumen of sheep and their relation to the intake and digestion fiber. Journal of Animal Science, 59, 772-783. https://doi.org/10.2527/jas1984.593772x

Van Soest, P. J., Robertson, J. B., \& Lewis, B. A. (1991). Methods for dietary fiber, neutral detergent fiber, and nonstarch polysaccharides in relation to animal nutrition. Journal of Dairy Science, 74, 3583-3597. https://doi.org/10.3168/jds.S0022-0302(91)78551-2

Vendramini, J. M. B., Sollenberger, L. E., Dubeux Jr., J. C. B., Interrante, S. M., Stewart Jr., R. L., \& Arthington, J. D. (2006). Concentrate supplementation effects on forage characteristics and performance of early weaned calves grazing rye-ryegrass pastures. Crop Science, 46, 1595-1600. https://doi.org/10.2135/ cropsci2005.11-0419

Vendramini, J. M. B., \& Arthington, J. D. (2008). Effects of supplementation strategies on performance of early-weaned calves raised on pastures. Professional Animal Scientist, 24, 445-450. https://doi.org/ 10.15232/S1080-7446(15)30880-9

White, L. D., \& McGinty, A. (1999). Stocking rate decisions: Key to successful ranch management (Pub. E-152). Texas A\&M University System. Retrieved from http://animalscience.tamu.edu/files/2012/04/beef-stockingrate-decisions.pdf 
Wiltbank, J. N., Gregory, K. E., Swiger, L. A., Ingalls, J. E., Rothlisberger, J. A., \& Koch, R. M. (1966). Effects of heterosis on age and weight at puberty in beef heifers. Journal of Animal Science, 25, 744-751. https://doi.org/10.2527/jas1966.253744x

\section{Copyrights}

Copyright for this article is retained by the author(s), with first publication rights granted to the journal.

This is an open-access article distributed under the terms and conditions of the Creative Commons Attribution license (http://creativecommons.org/licenses/by/4.0/). 